\title{
Hepatitis C Virus Reactivation Following COVID-I9 Vaccination - A Case Report [Corrigendum]
}

Lensen R, Netea MG, Rosendaal FR. Int Med Case Rep J. The authors apologize for this error. 2021;14:573-576.

Page 574, Results, third paragraph, Blood test on day 5, Leucocytes row, the text " $10^{9}$ " should read " $10^{8}$ ".

\section{Publish your work in this journal}

The International Medical Case Reports Journal is an international, peer-reviewed open-access journal publishing original case reports from all medical specialties. Previously unpublished medical posters are also accepted relating to any area of clinical or preclinical science. Submissions should not normally exceed 2,000 words or 4 published pages including figures, diagrams and references. The manuscript management system is completely online and includes a very quick and fair peer-review system, which is all easy to use. Visit http://www.dovepress.com/testimonials.php to read real quotes from published authors. 